\title{
Epidemics, indigenous communities, and public health in the COVID-19 era: views from smallpox inoculation campaigns in colonial Guatemala ${ }^{\dagger}$
}

\author{
Martha Few \\ Department of History, 108 Weaver Building, Pennsylvania State University, University Park, Pennsylvania 16801, USA \\ Corresponding author. E-mail: mzf52@psu.edu
}

\begin{abstract}
This article explores the tensions between well-intentioned humanitarianism and coercive colonialism during smallpox outbreaks in eighteenth-century Guatemala, when the state extended inoculation programmes to its predominant, culturally diverse Maya communities. Evidence from anti-epidemic campaigns shows public debates broadly comparable to the current COVID-19 crisis: debates about the measurably higher mortality rates for indigenous people and other marginalized groups; debates about the extent of the state's responsibility for the health of its peoples; and debates on whether or not coercion and violence should be used to ensure compliance with quarantines and public health campaigns. While inoculations provided medical assistance and material help to Maya communities, and resulted in demonstrably lower mortality rates from smallpox, at the same time they functioned as avenues for the expansion of colonial power to intervene in the daily lives of people in those communities, characterized by colonial actors as necessary for their own good, and for the broader public good.
\end{abstract}

Keywords: colonialism; humanitarianism; indigeneity; pandemic; smallpox; vaccine

When word arrived that a smallpox outbreak threatened the Audiencia of Guatemala in the early spring of 1794, Ignacio Beteta worked feverishly at his publishing house in the capital Nueva Guatemala to print copies of José Flores' new smallpox treatment manual. ${ }^{1}$ Flores was professor of medicine at the University of San Carlos and chief medical officer for the Audiencia, an area that stretched from modern-day southern Mexico through Central America. He was well known as the architect of the controversial programme that successfully introduced smallpox inoculation to residents in the capital back in 1780. His newly updated guide, Instruction for the Technique Used to Administer Smallpox Inoculation, and the Method to Cure This Disease, Adapted to the Nature and Way of Life of the Indians of the Kingdom of Guatemala, built on those experiences to provide a blueprint for the ambitious next stage: state-directed public health campaigns against smallpox that sought to extend inoculation programmes from the capital to its predominant, culturally diverse Maya communities. ${ }^{2}$

\footnotetext{
†I am grateful to Alexandria Herrera, Keisuke Hirano, Heidi Tworek, and two reviewers for their helpful comments on drafts of this article.

${ }^{1}$ This outbreak originated in the Atlantic port city of Campeche and had spread along trade routes through Tabasco and into Chiapas. Ignacio Beteta (1757-1827) was a printer and one of the founders of the Gazeta de Guatemala, colonial Central America's newspaper, established in 1794.

${ }^{2}$ José Flores, Instrucción sobre el modo de practicar la inoculación de las viruelas, y método para curar esta enfermedad, acomodado a la naturaleza, y modo de vivir de los indios del Reyno de Guatemala (Nueva Guatemala: D. Ignacio Beteta, 1794), A1-6118-56786, Archivo General de Centro América, Guatemala City, Guatemala (hereafter cited as AGCA). 
Audiencia officials sent printed copies of this manual to provincial capitals and important cities across colonial Central America. Public health doctors and their staff carried extra copies with them into the field that spring and summer as they fanned out into the northern and western highlands that bordered Chiapas to introduce smallpox inoculation to K'iche', Mam, Kaqchikel, Ixil, and other Maya ethnic groups.

Smallpox is, to date, the only disease eliminated as a public health threat, a process that took centuries of painstaking work until the World Health Organization declared it eradicated in $1980 .^{3}$ This remarkable achievement, however exceptional, depended on both the failures and success of early campaigns against smallpox like those in colonial Guatemala. Over time, these campaigns joined with other efforts over the next two centuries and more, and bridged major changes in the understanding of medicine, disease, and the human body, including the shift from Galenic-Hippocratic medicine to modern biomedicine, together forging the global history of the disease's ultimate elimination.

As the medical community, in collaboration with political leaders and others, work to identify the symptoms of COVID-19, separate out effective versus 'quack' treatments, and rush to develop a vaccine, history offers us a valuable perspective. The archival record describes individual, familial, community, and state responses to smallpox outbreaks from other places and time periods that resonate with our own experiences. This article explores how, then and now, we see comparable public debates at the intersection of epidemics, poverty, and ethnicity: on the measurably higher mortality rates from disease outbreaks for indigenous people, people of African descent, the poor, and other marginalized groups; about the extent of the state's responsibility for the health of its peoples; and about whether or not coercion and violence should be used on local populations to ensure compliance with quarantines, inoculation campaigns, and other public health mandates. Guatemala provides a compelling historical case study because of its large indigenous Maya population, and because José Flores, central to anti-smallpox campaigns there in the 1780s and 1790s, later travelled to Europe, where he drew on this accumulated knowledge to help design Spain's first empire-wide smallpox vaccination campaign, known as the Royal Maritime Vaccination Expedition (1803-06), a key turning point in the eventual elimination of smallpox. ${ }^{4}$

\section{Smallpox and 'the Great Dying'}

European participants in the wars of conquest and early colonization in the Americas, along with indigenous peoples who survived the waves of new infectious diseases that arrived in their wake, considered the mortality rates catastrophic. These events have led some scholars to argue that 'the Americas in the sixteenth and seventeenth centuries were in all likelihood the scene of the greatest destruction of lives in human history', while others have labelled these collective events as 'the Great Dying,. ${ }^{5}$ Alfred Crosby identified infectious disease as a key component of the 'Colombian exchange', arguing that the intentional and unintentional exchanges of biological agents - plants, animals, and especially epidemic diseases - had profound environmental consequences for the Americas. ${ }^{6}$ Among the most devastating were the so-called 'virgin soil' epidemics that included bubonic plague, smallpox, measles, influenza, and typhus, diseases to which indigenous peoples had no previous exposure. These brought death on a massive scale: $50-90 \%$

\footnotetext{
${ }^{3}$ Known small stores of smallpox exist in laboratories in the United States and Russia.

${ }^{4}$ See Gregorio Marañón Gonzalo Díaz de Yraola’s classic work, La vuelta al mundo de la expedición de la Vacuna (Seville: Escuela de Estudios Hispano-Americanos, 1948); and Martha Few, For All of Humanity: Mesoamerican and Colonial Medicine in Enlightenment Guatemala (Tucson: University of Arizona Press, 2015).

${ }^{5}$ W. George Lovell and Christopher H. Lutz, 'Conquest and Population: Maya Demography in Historical Perspective', Latin America Research Review 29, no. 2 (1994): 134. The phrase 'the Great Dying' comes from Alexander Koch, Chris Brierley, Mark M. Maslin, and Simon L. Lewis, 'Earth System Impacts of the European Arrival and Great Dying in the Americas after 1492', Quaternary Science Reviews 207 (2019): 13-36.

${ }^{6}$ Alfred Crosby, The Columbian Exchange: Biological and Cultural Consequences of 1492 (Westport: Greenwood Publishing Company, 1972).
} 
mortality rate of native peoples in Mesoamerica, along with the almost complete destruction of the Taíno, Arawak, and other indigenous peoples of the Caribbean during the first century after Columbus' arrival in 1492. ${ }^{7}$ The Maya population of colonial Central America saw a decline of almost 94\%, from roughly 2 million persons at European contact to a low of approximately 128,000 by the 1620 s. $^{8}$ Smallpox appeared at least as early as 1518 in Hispaniola, modern-day Haiti and the Dominican Republic, and the site of the first European settlement in the Americas; in 1520 in the Aztec capital city, Tenochtitlan; and in 1525 in the Inca empire Tawantinsuyu, where an estimated $50-75 \%$ of the population perished there even before the arrival of the military expedition led by Francisco Pizarro. ${ }^{9}$ Wars, forced displacement, and violence were thus crucial additional elements that magnified the impact of epidemics.

Waves of diseases such as smallpox continued throughout the colonial period, exacerbated by poverty, periodic food shortages, and the systemic violence of slavery and forced labour systems that structured the lives of Maya, African-descended, and multi-ethnic colonial subjects. Accounts found in the archive, usually written by elite men working in politics or religion during disease outbreaks, show a widespread acknowledgement that higher mortality rates continued to afflict the Maya in the seventeenth and eighteenth centuries. During a 1607-08 outbreak of peste (plague) in the capital city, Santiago de Guatemala, an eyewitness remarked on the noticeably higher mortality rates for Maya residents:

[The] widespread illness that the Indians of this land have [suffered from] during this past year has been a plague that kills these wretched Indians very quickly in two or three days, and in some cases suddenly, before they can be helped and before we can administer a treatment or cure, because as one returns to health, many others die. ${ }^{10}$

Food shortages exacerbated smallpox outbreaks for vulnerable populations, as in 1761, when members of the city council reported that the capital's Maya population and the multi-ethnic poor had higher death rates because they could not purchase the food and medicine they needed to sustain themselves and their families. In response, city officials gathered funds to distribute

${ }^{7}$ Demographic effects on indigenous populations varied temporally and regionally. See Suzanne Austin Alchon, A Pest in the Land: New World Epidemics in Global Perspective (Albuquerque: University of New Mexico Press, 2003).

${ }^{8}$ Despite this catastrophic decline, decades of structural racism, and, in the modern era, military rule and genocide, Maya peoples in the modern nation-state of Guatemala remain demographically resilient and today number more than twice the population at European contact, or some 4 million Maya people. Lovell and Lutz, 'Conquest and Population', 133; and W. George Lovell and Christopher H. Lutz, “A Dark Obverse”: Maya Survival in Guatemala, 1520-1994', Geographical Review 86, no. 3 (1996): 400.

${ }^{9}$ Noble David Cook, 'Sickness, Starvation, and Death in Early Hispaniola', Journal of Interdisciplinary History 32, no. 3 (2002): 349-86, provides evidence that smallpox may have arrived as early as Columbus' second voyage in 1493. Suzanne Austin Alchon, Native Society and Disease in Colonial Ecuador (Cambridge: Cambridge University Press, 1991), 13 and 35 , gives a smallpox mortality rate of 'up to seventy-five percent' for Tawantinsuyu before the arrival of the Pizarro expedition. For a comprehensive introduction to the historiography, see Alchon, A Pest in the Land, 'Appendix: The Demographic Debate', 147-72. Recent work on the history of epidemics and its effects on colonial populations has shifted to examining these topics from social and cultural history perspectives, emphasizing the key roles that local, Native American, and African and African-descended medical knowledge production and exchange played in medicine and healing in colonial societies. See especially Few, For All of Humanity; Pablo F. Gómez, The Experiential Caribbean: Creating Knowledge and Healing in the Early Modern Atlantic (Chapel Hill: University of North Carolina Press, 2017); Paul Kelton, Cherokee Medicine, Colonial Germs: An Indigenous Nation's Fight against Smallpox, 1518-1824 (Norman: University of Oklahoma Press, 2015); Paul Ramírez, Enlightened Immunity: Mexico's Experiments with Disease Prevention in the Age of Reason (Stanford: Stanford University Press, 2019); and Adam Warren, Medicine and Politics in Colonial Peru: Population Growth and the Bourbon Reforms (Pittsburgh: University of Pittsburgh Press, 2010). New research combining archival sources with environmental science has led some scholars to argue that the severe decline of indigenous populations in the wake of European colonialism had measurable effects on the Earth's system. See Koch et al., 'Earth System Impacts of the European Arrival'.

${ }^{10}$ Alonso Criado de Castilla to His Majesty, Guatemala, 1608, unpaginated, Guatemala 12, Archivo General de Indias, Seville, Spain (hereafter cited as AGI). 
directly to the city's poor, two-thirds of which went to the residents of Sagrario and San Sebastián, the parishes deemed most in need. ${ }^{11}$

While Flores and other political and medical elites in favour of using inoculation (inoculación) represented it as a new, modern tool in the public health fight against smallpox, the practice had existed for centuries in other parts of the world, including parts of China, the Middle East, and Africa. ${ }^{12}$ The technique was not systematically used as part of public health campaigns, however, until 1720 in Spain and the second half of the eighteenth century in Spanish America. ${ }^{13}$ Inoculation involved the removal of smallpox matter from someone who had a mild form of the disease and its placement into the body of an uninfected person using a lancet or other cutting instrument. The inoculated person would then come down with a mild form of the disease, and then hopefully survive to gain lifetime immunity. ${ }^{14}$ Vaccination (vacuna), which used the much safer cowpox to confer immunity to humans, came later to the fight against smallpox, in a method developed in 1796 and credited to the English physician Edward Jenner. ${ }^{15}$

\section{Colonialism and medical humanitarianism}

In the eighteenth century, the first public health campaigns to fight epidemics among indigenous and multi-ethnic populations in Latin America, and protect them from future outbreaks of these diseases, show changes in how the colonial state began to prioritize the health of its peoples. In colonial Guatemala, this came to include, at least in principle, the health of the Maya. The Audiencia's shift was accompanied by the development of medical humanitarianism, which combined the compassionate language of helping the sick, the poor, and indigenous peoples with advocating for the application of new Enlightenment advances in medicine to anti-epidemic campaigns against typhus, measles, and smallpox. Guatemala's humanitarianism in part had its origins in long-standing religious traditions of Christian responsibility towards the poor, the sick, and other marginalized populations, especially as they related to healthcare and hospitals. ${ }^{16}$ Over the course of the eighteenth century, colonial medical, political, and religious elites collaborated with these traditions, integrating them with the new medical sciences of the global Enlightenment as they argued in favour of state-directed public health campaigns. ${ }^{17}$

The themes of medical humanitarianism emerged even before doctors had the tools needed to successfully treat or cure smallpox. In 1769, a decade before the targeted use of smallpox inoculation in the capital for the first time, the physicians Manuel Ávalos y Porras and Francisco Desplanquez published Guatemala's first Audiencia-sanctioned treatment guide to tackle a concurrent outbreak of smallpox and measles that year. As in earlier epidemics, these men noted significant disparities in survival rates among various sectors of the city's population, reporting

\footnotetext{
${ }^{11 ‘}$ Haviendo representado el señor síndico la notoria enfermedad y epidemia general', Santiago de Guatemala, 29 May 1761, fol. 158v, A1-1799-11793, AGCA.

${ }^{12}$ For a good overview see F. Fenner et al., Smallpox and Its Eradication (Geneva: World Health Organization, 1988).

${ }^{13}$ Some comparative dates for the introduction of inoculation are Chile, 1760s; Peru, 1770s-1790s; Mexico, 1780s-1790s; and Puerto Rico, 1792. Few, For All of Humanity, 55-6 and 222, n. 166.

${ }^{14}$ Ibid., 3-5 and passim.

${ }^{15}$ Jenner and others built on observations that those who cared for cows and caught cowpox gained immunity from smallpox. Edward Jenner, An Inquiry into the Causes and Effects of the Variola Vaccinae (London: Sampson Low, 1798). The history of the development and global spread of the vaccine to combat smallpox is a fascinating one, though beyond the scope of this short article. For more on its introduction and use in colonial Central America, see Few, For All of Humanity, chap. 5, 'This Marvelous Fluid', 165-96.

${ }^{16}$ For the link between Christian charity and medical science, see Paula de Vos, 'The Apothecary in Seventeenth- and Eighteenth-Century New Spain: Historiography and Case Studies in Medical Regulation, Charity, and Science', Colonial Latin American Historical Review 13, no. 3 (2004): 249-85; Few, For All of Humanity.

${ }^{17}$ Humanitarianism has its origins in colonialism and the Enlightenment. For an introduction, see Michael Barnett, Empire of Humanity: A History of Humanitarianism (Ithaca: Cornell University Press, 2011).
} 
higher death rates among indigenous residents and the poor. ${ }^{18}$ This led the physicians to make the following recommendation:

In this matter ... Christian charity obliges us to care for these poor unhappy ones when they do not understand [the disease]. And for justice's sake (justicia) the Ministers are entrusted [with] the protection of these minors, and of the prelates and parish priests who watch over them for their benefit as if they were sheep in a flock. The Fiscal judges [that this] must be done in the current situation as these sicknesses have struck again, and because of the ruin to these poor ones, and the injury that the loss of so many tributary vassals would cause to the Crown. ${ }^{19}$

This quote shows the ways in which humanitarianism deployed in medical contexts combined paternalistic and colonial rhetorics that reinforced racial/ethnic hierarches even as it extended needed medical treatment to the multi-ethnic urban poor. The medical doctors who authored the instructions described the city's Maya residents as sheep in a flock and as minors, deserving of the help of Christian charity. In addition to parish priests, colonial secular elites such as medical doctors and government ministers now had the responsibility for ensuring that 'these poor ones' received material and monetary assistance. This language also lays bare the economic motivations for this help: that is, to ensure secure Maya populations whose labour and taxes provided the basis for the continued stability of the colonial state.

State-sanctioned use of smallpox inoculation in the capital in 1780 was controversial. Colonial elites in Guatemala and Spanish America read through materials written about this technique in works published in Europe and the Americas, and in inoculation-focused articles in newspapers that circulated in colonial society, including the gazettes of Mexico and Spain, which were available to interested readers in the capital. Pro- and anti-inoculation debates played out in in city council and university politics. Flores took the lead when smallpox again threatened in July that year, receiving permission from the president of the Audiencia to implement a centralized plan in the city, with the compromise stipulation that inoculation must be voluntary and not forced on anyone. $^{20}$

Nueva Guatemala experienced relatively unique circumstances that made this smallpox epidemic more threatening than usual. In 1780, the capital had only existed for about seven years. The previous capital, Santiago de Guatemala, was heavily damaged by earthquakes in 1773, and colonial elites decided to create the new capital in a nearby valley. This meant that, as the region faced smallpox in 1780, Nueva Guatemala was still under construction, with critical infrastructure problems that officials knew would exacerbate death rates for Maya and multi-ethnic poor residents. As yet there were no formal hospitals or pharmacies; high food costs plagued the city's new markets; and the lack of public fountains, which were still under construction, forced residents to obtain water for drinking, cooking, and washing from springs in the surrounding ravines. ${ }^{21}$

Inoculation organizers used the language of medical humanitarianism and compassion for families already struggling to meet their basic needs to frame their efforts and gain support and resources:

\footnotetext{
${ }^{18}$ Manuel Ávalos y Porras y Francisco Desplanquez, Méthodo que se ha de observer en la curación de sarampion y viruelas formado de orden del Superior Gobierno (Guatemala: J. de Arévalo, 1769), fol. 9v, A1-271-5909, AGCA: 'From what we have observed, these three illnesses [smallpox, measles, and "feverish measles"] do not pose the same danger to the rich, who have their medicines, comforts, and all the care that they require. And if they [the illnesses] cause deaths and fatalities in Indians [and] the poor, it is because of the neglect of their diets and their lack of food.'

${ }^{19}$ Ibid., fol. 7, capitalizations in original.

${ }^{20}$ Carlos Martínez Durán, Las ciencias médicas en Guatemala: Origen y evolución, 3rd edn (Guatemala City: Editorial Universitaria, 1964), 328-9.

${ }^{21}$ Sala Capitular de Guatemala, '1780 Peste Viruela', 10 July 1780, unpaginated, A1-4026-31001, AGCA.
} 
We are asking to receive the funds necessary to aid in the survival of families, and many live in poverty here even in a state of perfect health [non-epidemic times], and that the people have perished from losses suffered in the ruin of Santiago de Guatemala, [and because] of the costs of moving [to the new capital], the shortage and high price of food, and even the high cost of clothing. ${ }^{22}$

The city council worked with wealthy elite men, members of the clergy, and Flores and other medical specialists in a strategy typical of other urban areas facing an epidemic outbreak in the eighteenth century. By August, they had divided the city into four sectors and placed three to four elite men in charge of each. Audiencia officials provided some of the funding, and also solicited donations from Guatemala's prominent families to help offset the costs of the programme.

Sector leaders inspected homes and coordinated inoculations, distributed food, clothing, and bedding to the sick and their families, and kept meticulous records of their progress. Nueva Guatemala's city council then compiled these records in a way that provides a bleak picture of levels of poverty in the capital, revealing significantly higher rates of infection among the multi-ethnic and indigenous urban poor. By the end of August 1780, officials counted 8,667 residents sick with smallpox. Of those, they judged that roughly one-third, some 3,000 persons, were 'in extreme need of daily food', while another 3,000 had access to sufficient food but still required monetary support from the government to cover the costs of blankets, medicines, clothing, and other items. ${ }^{23}$ Thus, this acknowledgement by colonial officials that poverty exacerbated smallpox survival rates led to concrete actions to mitigate hunger and lack of resources, at least in a limited way during epidemics, expanding the responsibility for social assistance from the religious realm to include secular society as well.

While the surviving archival record does not contain evidence of inoculation's reception among city residents, it does provide basic statistics gathered by sector leaders that show its successes, and its limits. Towards the end of August 1780, the leaders of one of the city's sectors conducted a census to assess rates of infection and inoculation progress. They counted 20 residents successfully inoculated, all of whom recovered well from a mild form of the illness. Another 200 suffered from natural smallpox, people who either refused inoculation or did not receive it in time. ${ }^{24}$ Flores reported that by late August he had inoculated 200 persons 'of every kind', with only one death, a teenage girl who appeared to survive inoculation smallpox, only to die shortly after from a fever. ${ }^{25}$

\section{Extending inoculation campaigns to the Maya highlands}

The use of smallpox inoculation for the first time in the capital, combined with other treatment efforts that included quarantines and attention to food supplies and diet, dramatically improved survival rates there. Much of the rest of the Audiencia, however, did not have the benefit of inoculation, making contrasts with those regions compelling for those who advocated medical humanitarianism. We can see this in the words of Friar Juan Ramón Solis, who described the work that he performed during the epidemic ministering to sick and dying Ixil Maya in the highland town of Nebaj:

\footnotetext{
${ }^{22}$ Sala Capitular to the Real Junta, 5 September 1780, unpaginated, A1-4026-31004, AGCA.

${ }^{23}$ Sala Capitular, 23 August 1780, unpaginated, A1-4026-31004, AGCA.

${ }^{24}$ Sala Capitular, 23 August 1780, unpaginated, A1-4099-30999, AGCA.

${ }^{25}$ Reprinted in Methodo de la inoculacion de las viruelas que refiere M. de la Condaminé en su celebre memoria, sobre dicha inoculación. Traducida del idioma Francés al Castellano por D. Manuel Gonzáles de Batres (Nueva Guatemala: A. Sánchez Cubillas, 1780), 5, Wellcome Library, London (hereafter cited as WL).
} 
The work that I have had to do has been enormous, and there is no sick person that I have not visited, administering the sacraments to the adults, and praying evangelios over the children. I have ordered them [Nebaj residents] to leave the dead where they died in their sleeping rooms and not to bring them to the living areas as they usually do [for the wake]. This has more than doubled my work, and often I have to [kneel] on the floor so that I can confess them, five or six to a room. ${ }^{26}$

The successes with the 1780 anti-smallpox efforts and their contrasts with heart-wrenching scenes like those described by Friar Solis led an influential sector of colonial society that included Audiencia officials, members of the city council, and professors of medicine at the university to argue that inoculation had the potential to save Guatemala's Maya population and extend anti-smallpox efforts to rural areas and regional towns. ${ }^{27}$

As the next outbreak loomed in 1794, Audiencia officials advocated for the expansion of inoculation programmes to the Maya highlands north and west of the capital, and looked to the chief medical officer, along with faculty in the medical school at the University of San Carlos, to develop a detailed plan. Flores and others who participated in the introduction of smallpox inoculation in the capital gained insights from that experience which they then used to improve methods for subsequent outbreaks. Collectively, they made a key observation that colonial populations were more receptive to smallpox treatments when doctors and members of anti-smallpox campaigns used persuasion rather than force. Another insight gained from the 1780 inoculation efforts was the importance of strategic co-optation of Maya elders, medical specialists, and individuals, and of adapting medical instructions to Maya cultural practices where possible in revised epidemic treatment manuals. Evidence for adaptation and collaboration among practitioners of colonial and Maya medicine appears in Flores' 1794 inoculation manual. His choice of title makes this explicit by including the phrase 'Adapted to the Nature and Way of Life of the Indians of the Kingdom of Guatemala'. ${ }^{28}$ These strategies included not only rethinking how anti-smallpox campaigns practised inoculation in Maya communities, but also more fine-grained adaptations of guidelines for healthful foods and medicinal plants based on Central America's ecology of the cold mountainous highlands, hot and humid tropical lowlands, and temperate zones. ${ }^{29}$

Adaptation additionally involved active innovation and collaboration between various stakeholders, including colonial medical doctors, botanists, and others interested in natural history, and Maya medical specialists, community elders, and political office holders, in order to learn each others' medical knowledge and practices. Cross-cultural knowledge exchanges, and adaptation to the needs of local and Maya populations, began even earlier, during the 1780 epidemic, when Flores proposed a 'local method' of inoculation. In August, amid the first inoculation campaign, one of Guatemala's printing houses published a translation of a French Royal Academy of Sciences inoculation manual for distribution to officials involved in the city's anti-smallpox campaigns. The book included additional pages of instructions written by Flores, who called for integrating the Maya practice of using poultices made from cantárides, locally available medicinal beetles. ${ }^{30}$ We know today that this insect contains the chemical cantharidin, which irritates skin tissues. When prepared and applied to human skin, the insect substance causes blisters to rise that can then be exploited for medicinal purposes. The poultice proved effective at raising blisters that the inoculator could then easily cut open, facilitating the transfer of smallpox material from one body to another.

\footnotetext{
${ }^{26}$ Fray Juan Ramón Solis to Francisco Geraldino, Nebaj, 1 October 1780, fol. 17v, A1-4026-31004, AGCA.

${ }^{27}$ Reflecting in a report to the Audiencia at the end of the 1794 inoculation campaign, the alcalde mayor Prudencio de Cozar argued 'without [these measures] to save the Indians ... surely it would have been a huge catastrophe'. Prudencio de Cozar to la Real Audiencia, Quetzaltenango, 5 October 1795), fol. 7v, A1-389-8102, AGCA.

${ }^{28}$ Flores, Instrucción, title page.

${ }^{29}$ Ibid., 5-6, 8.

${ }^{30}$ Methodo de la inoculacion de las viruelas que refiere M. de la Condaminé, 4-5.
} 
The extraction of indigenous knowledge is a well-documented aspect of colonial exploitation, with the information circulated after it had been vetted, experimented with, and legitimized by colonial doctors and scientists. Printers published the work of Guatemalan intellectuals that drew on this knowledge, as well as key works of important foreign authors in translation, such as the French inoculation instructions. A number of scientific and medical works published by Guatemalan authors were reprinted in places including Mexico City, Madrid, Turin, London, and Paris. ${ }^{31}$ Maya medical knowledge circulated globally in the process, as when Flores published his influential work New Medicine Discovered in the Kingdom of Guatemala, for the Absolute Cure for the Horrible Illness Cancer, in which he introduced the cancer-curing powers of lizards native to a specific lake in Guatemala, a knowledge he gained from unnamed Maya men. ${ }^{32}$

Flores was not exceptional in this regard. Even those who did not speak a Maya language, or did not venture outside the capital, could still act as brokers of Maya medical knowledge, gained from formal and informal ties, and circulate it to interested readers in the Americas and Europe. This is what Mariano José Herrarte, a Recollect friar and self-trained medical botanist, did in response to the royal order circulated in the Americas by the Spanish crown in 1783 requesting samples of useful plants and information on their use. ${ }^{33}$ Herrarte described the medicinal properties of some thirty-six plants used in Maya medicine in seven manuscript notebooks. He also made it clear that he had never visited a tributary Maya town (pueblo de indios), nor did he speak any of the more than twenty Maya languages. Instead, he had acquired this knowledge simply by living and interacting with people in the capital. Despite these limits, Herrarte assured readers that he had indeed obtained authentic indigenous knowledge: 'they [the Maya] have confirmed to me the various [medicinal] virtues of herbs and trees'. ${ }^{34}$ These included botanical ingredients used in treatments of infectious diseases such as yellow fever (known in the colonial period as vómito prieto, or black vomit) and syphilis.

Moreover, Flores' experience from the 1780 inoculation experiments solidified his conviction that inoculation should not be forced on anyone, and no violence should be used in the anti-epidemic campaigns, placing the rhetoric of medical humanitarianism into practice through official treatment manuals. As he explained in the 1794 manual: 'The principal requisite for a successful [inoculation] procedure is that the military officer, the Spanish, and the [Maya] elites of the [Maya] towns follow these instructions and [inoculate] carefully and gently, and take extreme care not to use violence and not to terrify the Indians. ${ }^{35}$ This perspective worked in concert with his adaptation of inoculation to Maya populations. Flores then elaborated on the use of medicinal beetles to prep the recipient's body for smallpox transfer. When reports filtered back that European-style lancets used to cut open smallpox blisters to remove infected materials as part of inoculation terrified children and their parents, and that 'they shuddered to see the lancet, saying that we were going to kill their children with this procedure', Flores proposed that inoculators simply substitute the chay (pl. chayes), a Mesoamerican-style cutting blade made from obsidian or flint. ${ }^{36}$

\footnotetext{
${ }^{31}$ For more, see Few, For All of Humanity, especially the introduction, 'Medicine and Colonialism in Enlightenment Guatemala', 3-28.

${ }^{32}$ José Flores, Específico nuevamente descubierto en el Reyno de Goatemala [sic], para la curación radical del horrible mal de cancro (México City: D. Felipe de Zuñigay Ontiverso, 1782). This work, also published in Madrid in 1782, generated a lively debate about medicinal lizards. It was reprinted in 1783 in Cádiz, in 1784 in Polish translation in Warsaw and in French translation in Lausanne, and in Italian translation in Turin in 1784 and Venice in 1785. See Miruna Achim, Lagartijas medicinales. Remedios americanos y debates científicos en la ilustración (México, DF: Consejo Nacional para La Cultura y Las Artes, 2008).

${ }^{33}$ Mariano José Herrarte, 'A Return Describing Plants of Medicinal Value Used by the Indians of Guatemala', Guatemala, 1784, unpaginated, WL.

${ }^{34}$ Ibid.

${ }^{35}$ Flores, Instrucción, 3.

${ }^{36}$ 'Método en que se práctica la inoculación de viruelas en los pueblos ferozoz Indios', 3 February 1798, unpaginated, Guatemala 648, AGI.
} 
In this way, help came to Maya communities, but it would be a mistake to consider the Maya as victims waiting to be saved by colonial medicine. Female and male Maya specialists called curanderos sangradores were widely recognized in colonial society for their skills using chayes for medicinal bloodletting and wet cupping. ${ }^{37}$ In fact, even some Spaniards preferred to be bled with chayes over the lancet, as did the chronicler Francisco Ximénez, writing earlier in the eighteenth century: 'Here I advise counsel from twenty-five years of experience that I have, and that others have had, of not being bled with anything other than the chay. ${ }^{38}$ Indigenous peoples of Mesoamerica, including the Maya, had sophisticated medical cultures throughout the colonial period, cultures which exist to the present day. Flores' instruction that 'the Indians can easily substitute their obsidian blades that they use for medicinal bleeding' acknowledged the sophistication of Maya medicine. ${ }^{39}$

This statement also indicates that Flores intended for Maya healers to practise inoculation in their own communities, and thus aid in its spread by integrating Maya themselves into antismallpox campaigns. ${ }^{40}$ Parish priests helped medical teams to identify 'the most capable ladinos and Indians to inoculate and care for the sick' (ladino referred to a Maya person who spoke Spanish or was bilingual, and who dressed in European clothing rather than Maya traje). ${ }^{41}$ Reports from regional political officials such as Francisco Chamorro record successfully teaching Maya healers to use inoculation: 'Despite the Indians' opposition to the lancet procedure and the fear they had, I taught them the practice of inoculation, and in this way prevented hundreds of deaths. ${ }^{42}$ Even though Chamorro credits himself with preventing 'hundreds of deaths', what is clear here is that some among the Maya quickly saw the benefits of smallpox inoculation, learned the procedure, practised it in their own communities, and taught it to others.

Reports such as Chamorro's, however, only approximate what the Maya individually and collectively thought about inoculations and other tools used in the fight against smallpox because they were produced by, and mediated through, colonial public health doctors, political officials, and priests. Nevertheless, eyewitness accounts of mass inoculations sometimes capture, perhaps unintentionally, Maya medical specialists participating in mass inoculations alongside colonial medical doctors. ${ }^{43}$ Reports from Maya communities in the province of Totonicapán show the key role of Maya women healers, who added a layer of Mesoamerican ritual practice to the procedure: after the inoculation, 'the mother took the child in her arms and presented him to the mountains, burning much copal, asking the hills for the health of her child. Then she returned to the church, asking that the patron saint of the town save him from death. ${ }^{44}$ The mother in this source may have been the child's actual mother, or she may have been a medical-ritual specialist who combined Maya healing strategies, including burning copal incense and invoking the animate power of the landscape, with prayers to the town's patron saint as the protector of the community and its residents. Interestingly, Chamorro, the regional political leader who wrote this report, did not characterize the woman's participation as anything out of the ordinary, a strategic concession to Maya medical-ritual cultures to ease the inoculations that took place in public in the town square, with the entire community assembled, and with military men, medical entourages, and local priests all present.

\footnotetext{
${ }^{37}$ Few, For All of Humanity, 15, 145-8.

${ }^{38}$ Francisco Ximénez, Historia natural del reino de Guatemala (Guatemala: José Pineda Ibarra, 1967).

${ }^{39}$ Flores, Instrucción, 5

${ }^{40}$ Ibid.

${ }^{41}$ Ibid., 6.

${ }^{42}$ Francisco Chamorro to the king, Nueva Guatemala, 31 May 1800, unpaginated, Guatemala 648, AGI.

${ }^{43}$ Francisco Chamorro to the king, Nueva Guatemala, 3 February 1798, fols. 2-3, Guatemala 648, AGI.

${ }^{44} \mathrm{Copal}$ is a resin used as a ritual substance by Mesoamerican peoples. See 'Método en que se practica la inoculación de viruelas en los pueblos ferozoz Indios'.
} 
Smallpox inoculation worked, bringing with it significant declines in mortality rates among all racial and ethnic groups. Audiencia governors such as Agustín de las Quentas Zayas of Ciudad Real de Chiapas, argued for the successes of the 1796 campaigns by compiling censuses that compared mortality rates with the 1780 epidemic. In the heavily Maya districts of Zendales, San Bartolomé, and Comitán that de las Quentas governed, he reported only 218 deaths among the 8,915 persons inoculated. He contrasted this with the 1780 epidemic, where 9,943 perished. ${ }^{45}$ The circulation of information, cures, and inoculation guidelines in colonial Central America during outbreaks and their aftermath shows that, to succeed, colonial medicine needed to recommend therapies based on local conditions and adapt to the medical cultures of its large majority Maya population. Yet for the Maya, the extension of anti-epidemic campaigns also came at the cost of direct colonial interventions into their culture, medicine, living practices, diet, and even dress. Centralized efforts that provided medical assistance and material help to afflicted families and communities simultaneously functioned as another avenue for colonial power to intervene in the daily lives of the Maya and the poor, now through public health medicine, characterized by colonial actors as necessary for their own good, and for the broader public good.

\section{Violence and coercion in colonial public health campaigns}

While colonial anti-smallpox campaigns in Guatemala could, in theory, be flexible and allow for the integration of Maya medical chayes and blister beetle poultices, anti-smallpox campaigns characterized other Maya medical practices as causing the disease to spread. This was the case in particular for the temascal, a ritual-medical steam bath that has formed a cornerstone of Mesoamerican medical cultures since ancient times. Maya healers treated epidemic diseases using temascales, including typhus, measles, and smallpox. They had broader applications past epidemic care and were widely used to maintain health, mediate pregnancy and childbirth, and treat general illnesses in individuals and families. Curanderos sangradores also used temascales to treat patients with medical bloodletting and cupping, the room filled with heated water vapours mixed with burning medicinal materials from plants, animals, and other ingredients from the local environment. ${ }^{46}$

Those who led anti-epidemic campaigns, however, frequently complained about temascales and periodically sought to destroy the buildings and outlaw their use, especially during outbreaks. Reports from Maya areas during the 1780 smallpox epidemic claimed that their use in highland communities had facilitated the spread of smallpox, so much so that subsequent anti-epidemic campaigns explicitly outlawed their use. Friar Solis, who had compellingly described his work in Nebaj among the Ixil Maya ministering to smallpox patients, also reported to Audiencia officials that temascales facilitated disease spread and increased mortality rates. He repeatedly warned his parishioners from the pulpit not to treat the sick in temascales. Medicinal temascal use continued, however, despite the fact that the town's Maya alcaldes (political office holders) walked through the streets warning against the dangers of their use. ${ }^{47}$

Beginning in the 1790s, Audiencia-sanctioned treatment manuals for smallpox, typhus, and measles explicitly outlawed temascal use. Flores himself warned of their dangers: 'Do not let them use temascales, because the way that they Indians use them is very bad for those sick with typhus. The Indian justices need to monitor this. ${ }^{48}$ Others remarked on the ubiquitous presence of temascales across the highlands, where many of even the most modest dwellings in tributary

\footnotetext{
${ }^{45 ‘}$ 'Gobernador de Chiapa sobre sanidad', Ciudad Real, 6 October 1796, unpaginated, estado 37, no. 55, AGI.

${ }^{46} \mathrm{Few}$, For All of Humanity, 49, 60-1, 68-71.

${ }^{47}$ Fray Juan Ramón Solis to Francisco Geraldino, Nebaj, 1 October 1780, fols. 36-7, A1-6097-55507, AGCA.

${ }^{48}$ José Flores, 'Ynstruccion para curar los tabardillos que se padecen en el Pueblo de Jacaltenango y otros de la Alcaldia Mayor de Totonicapán', 19 November 1796, fol. 9v, A1-6101-55666, AGCA.
} 
Maya towns had one for family use: '[The Maya] have such a passion for temascal use, that it is the only and general treatment used for every sickness. ${ }^{49}$ Members of anti-epidemic campaigns saw Maya medical specialists who healed in temascales as subverting the state-mandated guidelines, and largely agreed that 'frequent temascal steam baths, nudity, hunger, and lack of care' exacerbated epidemic outbreaks. ${ }^{50}$

In fact, medical doctors and regional political officials considered temascal use so intractable that they brought in military men to systematically destroy these buildings in highland Maya towns. Local leaders argued that they had to resort to violence and threat of violence to ensure that Maya residents adhered to state-sanctioned smallpox treatment guidelines. Soloma parish in the Cuchumatán mountains was one of these areas. The province's political leader, Francisco Chamorro, who led the medical campaigns to the five parish towns there, complained that the Maya's 'barbarous customs' (sus bárbaras costumbres) of temascal use and widespread resistance prevented them from inoculating the residents. He reckoned that the medical team had only managed to inoculate two-thirds of the town of Santa Eulalia. The rest of the residents suffered from natural smallpox, with a $25 \%$ mortality rate. In cases like Santa Eulalia, frustrated colonial authorities revitalized well-worn racialized colonial tropes of 'barbarous Indians' to justify the inclusion of soldiers as members of highland medical campaigns and use them to threaten violence, including the destruction of temascales. Chamorro also complained that, because residents of the nearby town of San Mateo Ixtatán so stubbornly resisted inoculation, he ordered the soldiers to destroy the town's temascales. ${ }^{51}$ The destruction of temascales in Maya communities and the forced removal of the sick to quarantine in temporary smallpox hospitals guarded by armed men were linked strategies to ensure the compliance of Maya towns. ${ }^{52}$

Thus, despite the acknowledgement among influential sectors of colonial elites in the capital that persuasion and co-optation worked much more effectively than force, regional officials working on the ground often resorted to fear-based tactics. This came to include armed militia soldiers and local men hired to enforce quarantines and act as guards for inoculators and other members of the medical team as they treated Maya who rejected the Audiencia's anti-smallpox guidelines. ${ }^{53}$ The soldiers also worked with the medical teams to identify and destroy the homes and belongings of people who perished from smallpox, typhus, and measles, extremely contentious acts that left survivors destitute. ${ }^{54}$ Violence and threat of violence to enforce state-mandated anti-epidemic measures did not always achieve their goals. When the medical team working in Nebaj became frustrated that Ixil residents refused to present themselves for mandated bleeding therapies, they resorted to going house to house to force them to submit to the procedure. Even with direct intervention into homes, the parish priest and the doctor who led the medical team reported widespread 'resistance and evasion' when household members refused treatment, hid the sick, or simply fled the town. ${ }^{55}$

The use of violence extended to quarantine enforcement. The towns of Soloma parish such as Santa Eulalia and San Mateo Ixtatán, as well as those in neighbouring Jacaltenango parish, all located along the busy Camino Real and other trade routes that connected southern Mexico to Guatemala's capital, experienced outbreaks first, as smallpox spread south-east from Chiapas along those same routes. The president considered it critical to stop the epidemic there,

\footnotetext{
${ }^{49}$ Mariano Francisco Zenteno to Prudencio de Cozar, Quetzaltenango, 6 August 1804, fol. 49v, A1-194-4969, AGCA.

${ }^{50}$ Mariano Larrave to Chief Medical Officer José Antonio Córdova, Santa Eulalia, 2 January 1804, fol. 5v, A1-194-4969, AGCA.

${ }^{51}$ Francisco Chamorro to the President, Santa Eulalia, 6 September 1795, fol. 7r-v, A1-191-3904, AGCA.

${ }^{52}$ ‘Real Provision en que se conceden del fondo de comunidad del pueblo de Santa Eulalia', 1804, fols. 43-6, A1.24-609155306, AGCA.

${ }^{53}$ Prudencio Cozar to the Real Audiencia, Quetzaltenango, 5 October 1795, fols. 1-7v, A1-389-8102, AGCA.

${ }^{54 ‘ G o v i e r n o ~ d e ~ T o t o n i c a p a ́ n ’, ~ 1797, ~ f o l . ~ 7 r-v, ~ A 1-191-3904, ~ A G C A . ~}$

${ }^{55}$ Fray Francisco Abello to Francisco Aguirre, Nebaj, 2 January 1798, fol. 4, A1-191-3909, AGCA.
} 
before it spread south to the capital and the rest of the Audiencia. He sent instructions to regional political leaders and provided funding for militarized quarantine lines along the moving borders between infected and uninfected towns. ${ }^{56}$

In Totonicapán, one of these leaders was Francisco Chamorro, a former militia captain. ${ }^{57} \mathrm{He}$ applied his military experience and knowledge of the region's mountainous geography to set up four strategic quarantine guard posts. Each post employed at least two soldiers and one 'Indian', a local man who knew the area and was bilingual in Spanish and at least one of the regional Maya languages. ${ }^{58}$ Roving, armed mounted guards conducted periodic sweeps along the lesser-known mountain paths. Local residents, however, desperate to take their goods and animals to market, or to escape the epidemic, attempted to make their way through the mountainous terrain where the soldiers could not follow, or along routes unknown to them. ${ }^{59}$

Prudencio Cozar blamed a Maya man and his infected young nephew for bringing smallpox from Tuxtla in Chiapas to the highland town of Tajumulco in the district that he governed. They managed to evade the quarantine lines by walking 'through unknown ravines and cliffs located far from the guards' ${ }^{60}$ Cozar wrote that, as soon as he heard of the outbreak, 'I went there at once, and I removed him [the Maya boy] to a milpa [likely a small farm] seven leagues from the town, far from other houses in that area.' He and the armed guards who accompanied him also forcibly removed and quarantined three other children from the same home who had been exposed to the boy's smallpox. ${ }^{61}$

Such heavy-handed use of threat and coercion that linked militia soldiers with public health campaigns, and the forced removal of infected children from their parents, had some success in the short term in preventing further outbreak. In the medium term, however, and especially over the next decade as multi-year, concurrent outbreaks of measles and typhus repeatedly burned through the region, the use of force and coercion served to increase mistrust of the medical campaigns in Maya communities. Doctors, inoculators, and regional political officials filed reports that Maya towns outright refused medical treatments, or its residents fled to disperse into the highland montes (forests) as soon as word arrived that a medical campaign was on its way. Oher Maya towns used violence themselves, or threatened it, against medical campaign workers. ${ }^{62}$

The reach of medicine through state-directed public health campaigns extended the symbolism and practice of colonial rule in Guatemala, including its majority Maya populations, in new and intimate ways and on a massive scale not seen since the conquest and early colonization period. Medical interventions into Maya communities as part of inoculation efforts and other antiepidemic campaigns were part of a broader historical pattern that structured colonial governance over its subjects. The methods and personnel used for medical campaigns bear similarities to earlier religious conversion efforts that sought to intervene and reshape Maya worldviews, as well as to the forced resettlement of subject populations into tributary towns (pueblos de indios), where residents could be monitored by priests and political officials to ensure that they met their tribute and labour requirements. What made medical interventions particularly intrusive were the ways that the violence and racial/ethnic hierarchies that characterized colonial rule in Guatemala came to be re-enforced through state-directed public health campaigns.

\footnotetext{
${ }^{56}$ Francisco Chamorro to the President, Santa Ana Huista, 19 August 1795, Guatemala 648, AGI.

${ }^{57}$ Francisco Chamorro to the king, Nueva Guatemala, 3 February 1798, unpaginated, Guatemala 648, AGI.

${ }^{58}$ 'Ordenes para los que cuidan los caminos' Huehuetenango, 6 August 1795), fols. 1-2, and Francisco Chamorro to the Superior Gobierno, Todos Santos Cuchumatán, 8 January 1795, fol. 10v, both A1-191-3904, AGCA.

${ }^{59}$ Francisco Chamorro to the Superior Gobierno, August 1795, fol. 10v, A1-191-3904, AGCA.

${ }^{60}$ Prudencio Cozar to the Real Audiencia, Quetzaltenango, 5 October 1795, fol. 4v, A1-389-8102, AGCA.

${ }^{61}$ Ibid., fol. 5 .

${ }^{62}$ See Few, For All of Humanity, on the varied Maya responses to anti-epidemic campaigns.
} 


\section{Parallels for the COVID-19 era}

Despite vastly different political systems, conceptions of race and ethnicity, and frameworks for understanding how inoculations and disease worked, themes emerge from colonial anti-smallpox campaigns in Guatemala that resonate with today's COVID-19 pandemic. Epidemic outbreaks across diverse historical contexts allow us to see humankind at its best and worst. At their best, state, religious, and grassroots humanitarian efforts, despite their potentially coercive aspects, help communities and individuals in need. In Guatemala, the NGO Wuqu' Kawoq/Maya Health Alliance works to spread information on COVID-19 in rural Guatemala, where still today more than $50 \%$ of the population speak one of more than twenty Maya languages. ${ }^{63}$ Among other efforts, they have created radio programmes in Kaqchikel, K'iche' and Tz'utujil Maya languages to make COVID-19 information accessible to remote rural areas where people are sheltering in place and have little to no internet access. ${ }^{64}$

Indigenous communities have been proactive in creating their own anti-epidemic measures locally when state or federal measures are non-existent or fall short. In March 2020, the Haida Nation in British Columbia, alarmed at COVID-19's spread, outlawed visitors and leisure travel to Haida Gwaii to protect its residents. ${ }^{65}$ In the same month, the Navajo Nation, which spans parts of Arizona, New Mexico, and Utah, declared a public health emergency and ordered a stay-athome/shelter-in-place order for residents to quarantine and isolate themselves. Leaders also began a water and food distribution programme to residents living in remote areas. ${ }^{66}$

COVID-19 also reminds us of the enduring and more troubling patterns around epidemics and health. The United Nations High Commissioner for Human Rights, Michelle Bachelet, recently argued that 'rising disparities in how COVID-19 is affecting communities, and the major disproportionate impact it is having on racial and ethnic minorities, including people of African descent, have exposed alarming inequalities within our societies', especially in Brazil, the United Kingdom, the United States, and France. ${ }^{67}$ In Brazil, a global epicentre of COVID-19, African-descended residents of the state of São Paulo are $62 \%$ more likely to die from the virus than whites. ${ }^{68}$ Indigenous peoples living in the Amazon region fear that the pandemic's toll on their village elders, political leaders, and traditional healers 'may inflict irreparable damage on tribal knowledge of history, culture and natural medicine'. ${ }^{69}$ The use of racial/ethnic profiling during outbreaks can lead to decades of mistrust or resistance towards the government and public health efforts. ProPublica reported in June 2020 that Lovelace Women's Hospital in Albuquerque, New Mexico had implemented a secret testing protocol for pregnant women asymptomatic for COVID-19 if they 'appeared' to be Native American. This led to the pre-emptive separation of Native American newborns from their mothers for women who gave birth before receiving the results of COVID-19 testing. ${ }^{70}$ Such actions, compounded by the racial/ethnic stereotyping of Asians, immigrants, and

\footnotetext{
${ }^{63}$ Wuqu' Kawoq/Maya Health Alliance, http://www.wuqukawoq.org/.

${ }^{64}$ 'Nuestra Respuesta al COVID-19', http://www.wuqukawoq.org/nuestra-respuesta-al-covid-19?lang=es.

${ }^{65}$ 'Haida Gwaii State of Emergency Due to Covid-19', 23 March 2020, http://www.haidanation.ca/ and http://www. haidanation.ca/?page_id=10793.

${ }^{66}$ Navajo Department of Health, Public Health Emergency Order no. 2020-003, 20 March 2020, https://www.navajo-nsn. gov/News\%20Releases/NNDOH/2020/March/NDOH\%20Public\%20Health\%20Emergency\%20Order\%202020-003\%20Dikos\% 20Ntsaaigii-19.pdf.

${ }^{67}$ United Nations Human Rights Office of the High Commissioner, 'Disproportionate Impact of COVID-19 on Racial and Ethnic Minorities Needs to Be Urgently Addressed', 2 June 2020, https://www.ohchr.org/EN/NewsEvents/Pages/DisplayNews. aspx?NewsID $=25916 \&$ LangID $=\mathrm{E}$.

${ }^{68}$ Ibid.

${ }^{69}$ Dom Phillips, “'We are facing extermination': Brazil Losing a Generation of Indigenous Leaders to COVID-19', Guardian, https://www.theguardian.com/global-development/2020/jun/21/brazil-losing-generation-indigenous-leaderscovid-19?CMP=oth_b-aplnews_d-1.

${ }^{70}$ Bryan Furlow, 'A Hospital's Secrect Coronavirus Policy Separated Native American Mothers from Their Newborns', ProPublica, 13 June 2020, https://www.propublica.org/article/a-hospitals-secret-coronavirus-policy-separated-native-americanmothers-from-their-newborns.
} 
other groups as amplifying the pandemic's spread, and the politicization of mask-wearing and stayat-home orders in the absence of a vaccine, also warns that we should not consider vaccines as a quick solution, especially in the context of current anti-vaxxer movements across the globe, and instead to recognize the long, contested history of their creation and use. ${ }^{71}$

Martha Few is Professor of Latin American History and Gender, Women's, and Sexuality Studies at Pennsylvania State University. She is Senior Editor of the Hispanic American Historical Review. Her research concentrates on the histories of Maya peoples during Spanish colonial rule in Guatemala, Central America, and southern Mexico through the lenses of medicine and public health, gender and sexuality, environmental history, and human-animal studies. Her recent books include For All of Humanity: Mesoamerican and Colonial Medicine in Enlightenment Guatemala (2015) and Baptism Through Incision: The Postmortem Cesarean Operation in the Spanish Empire (2020).

\footnotetext{
${ }^{71}$ Loveday Morris and William Glucroft, 'Prospect of a Coronavirus Vaccine Unites Anti-Vaxxers, Conspiracy Theorists and Hippie Moms in Germany', Washington Post, 3 July 2020, https://www.washingtonpost.com/world/europe/coronavirusvaccine-anti-vaxx-germany/2020/07/02/da7efc7e-acba-11ea-a43b-be9f6494a87d_story.html.
}

Cite this article: Few M. 2020. Epidemics, indigenous communities, and public health in the COVID-19 era: views from smallpox inoculation campaigns in colonial Guatemala. Journal of Global History 15: 380-393, doi:10.1017/S1740022820000297 